\title{
MENGUKUR KINERJA DESENTRALISASI ADMINISTRASI DI KOTA KUPANG
}

\author{
I Putu Yoga Bumi Pradana \\ Fakultas Ilmu Sosial dan Ilmu Politik, Universitas Nusa Cendana, Indonesia \\ yoga.pradana@staf.undana.ac.id
}

\begin{abstract}
This article aims to analyze the performance of the local government of the City of Kupang in carrying out administrative decentralization from the perspective of public service quality and community satisfaction surveys in the city of Kupang. This study uses descriptive qualitative methods and data collection was carried out through observation, surveys, interviews, and findings from literature studies, as well as secondary data studies. Informants from this study include, employees of the Population and Civil Registry Office, the Investment and One-Stop Integrated Services Office, and the Kupang City Lerik SK Hospital. In addition, there were 120 respondents to measure SKM in the field of cleanliness and clean water services in six districts of Kupang City which were determined using accidental sample techniques. The results showed the fact that the value of service quality in the area of population and health is still categorized as $C$ or not good while in the one-stop integrated service sector it has a value of $B$ or good. While the results of the community satisfaction survey show that only the health and integrated one-door services are categorized as good while the population, cleaning and water services are categorized as poor.
\end{abstract}

Keywords : Decentralization, Public Service, Community Satisfaction Survey (SKM)

\begin{abstract}
ABSTRAK
Artikel ini bertujuan untuk menganalisis kinerja pemerintah Daerah Kota Kupang dalam melaksanakan desentralisasi administrasi dilihat dari perspektif kualitas layanan publik dan survey kepuasan masyarakat di Kota Kupang. Penelitian ini menggunakan metode deskriptif kualitatif dan metode pengumpulan data menggunakan teknik observasi, survey, wawancara, dan temuan dari kajian literatur, maupun kajian data sekunder. Informan dari penelitian ini meliputi, pegawai Dinas Kependudukan dan Pencatatan Sipil, Dinas Penanaman Modal dan Pelayanan Terpadu Satu Pintu, dan Rumah Sakit SK Lerik Kota Kupang. Selain itu, terdapat120 responden untuk mengukur SKM pada bidang kebersihan dan pelayanan air bersih di 6 (enam) kecamatan Kota Kupang yang ditentukan menggunakan teknik sampel aksidental. Hasil penelitian menunjukkan fakta bahwa nilai kualitas layanan pada bidang kependudukan dan kesehatan masih dikategorikan $\mathrm{C}$ atau kurang baik sedangkan pada bidang pelayanan terpadu satu pintu sudah bernilai B atau baik. Sedangkan hasil dari survey kepuasan masyarakat menunjukan bahwa hanya bidang kesehatan dan pelayanan terpadu satu pintu saja yang dikategorikan baik sedangkan bidang kependudukan, layanan kebersihan dan layanan air bersih dikategorikan kurang baik.
\end{abstract}

Kata Kunci: Desentralisasi Administrasi, Pelayanan Publik, Suvey Kepuasan Masyarakat (SKM) 


\section{PENDAHULUAN}

Dalam dua dekade terakhir, banyak negara di dunia telah mengalami reformasi sistem administrasi publik mereka dan telah mentransfer pengambilan keputusan wewenang dari pemerintah pusat ke pemerintah daerah (Litvack 1998; Crook \& Manor 1998) atau yang lebih dikenal dengan istilah desentralisasi. Indonesia sendiri secara eksplisit menerapkan kebijakan desentralisasi sebagai basis paradigma pemerintahannya diawali sejak disahkannya Undang-Undang Nomor 32 Tahun 2004 yang kemudian kembali disempurnakan melalui diterbitkannya Undang-undang Nomor 23 Tahun 2014 tentang Pemerintahan Daerah.

Smith (1985) mengatakan bahwa dasar filosofis yang menjadi alasan diterapkannya kebijakan desentralisasi dalam suatu organisasi pemerintahan yaitu (1) meningkatkan kualitas pelayanan publik di daerah, (2) mendekatkan pemerintah kepada masyarakat, (3) wadah demokratisasi di daerah, dan (4) meningkatkan kapasitas pemerintahan daerah dalam mengelola sumber daya alam sehingga diharapkan melalui penerapan otonomi daerah, pemerintah daerah melalui diskresi lokalnya mampu menjadi self local goverment.

Secara umum, desentralisasi dibedakan atas 3 (tiga) bentuk yaitu desentralisasi Politik, desentralisasi administrasi dan desentralisasi fiskal. Namun, artikel ini memfokuskan kajiannnya pada desentralisasi administrasi yang dimaknai sebagai atribusi otoritas pengambilan keputusan untuk tingkat pemerintahan yang lebih rendah sehubungan dengan kebijakan publik dan pemberian layanan publik (Schneider 2003:37-38; Hossain 2010:3). Umumnya terminologi desentralisasi administrasi dikenal dengan 3 (tiga) istilah berbeda seperti dekosentrasi, delegasi dan devolusi (Litvack, 1999).

Sehubungan dengan hal di atas, Litvack berpendapat bahwa fungsi utama dari desentralisasi administrasi untuk meningkatkan kapasitas local goverment dalam memberikan pelayanan publik yang berkualitas dalam rangka mendukung pembangunan ekonomi dan meningkatkan kesejahteraan local people. Desentralisasi administrasi dalam UU No.23/2014 tercermin pada adanya pembagian urusan antara pemerintah pusat dan daerah yang pada akhirnya menyebabkan munculnya urusan wajib 
dan urusan pilihan dari suatu pemerintahan daerah.

Konseksuensi dari otonomi daerah, menjadikan pemerintah daerah memiliki kewenangan yang sedemikian besar. Namun demikian, peemerintah daerah juga diperhadapkan dengan berbagai tuntutan masyarakat terhadap pelayanan yang diberikan. Tuntutan masyarakat terhadap pelayanan yang diberikan pemerintah, tidak hanya dilihat dari aspek kuantitas, melainkan pula aspek kualitas. Aspek kualitas pelayanan, merupakan isu sentral yang kini mengemuka diberbagai daerah. Kualitas pelayanan berhubungan erat dengan pelayanan yang sistimatis dan komprehensif, yang lebih dikenal dengan konsep pelayanan prima (Sinambela, dkk, 2011).

Kota Kupang sebagai bagian integral dari sistem pemerintahan Negara Kesatuan Republik Indonesia, merupakan salah satu daerah otonom yang menjalankan fungsi-fungsi desentralisasi baik desentralisasi politik, desentralisasi administratif maupun desentralisasi fiskal. Pembahasan pada penelitian ini sesungguhnya lebih tertuju pada aspek desentralisasi administratif yang dilaksanakan oleh pemerintah Kota Kupang didalam memberikan pelayanan publik yang berkualitas.
Pemerintah Kota Kupang, sebagaimana pemerintah daerah kabupaten/kota lain di Indonesia, menghadapi berbagai permasalahan pelayanan publik. Hal ini dibuktikan dengan adanya indikasi ketidakpuasan masyarakat yang dicerminkan dari sejumlah keluahan masyarakat atas kualitas layanan disediakan oleh Pemerintah Kota Kupang pada bidang kependudukan dan pencatatan sipil. Berikut ini disajikan data berkaitan dengan Tingkat Kepuasan Masyarakat terhadap Prosedur Pelayanan pada pemerintah Kota Kupang pada tabel 1 di bawah ini:

Tabel 1. Kepuasan Masyarakat Terhadap Prosedur Pelayanan

\begin{tabular}{|c|c|c|}
\hline Kategori & Frekuensi & Persentase \\
\hline Puas & 16 & $32 \%$ \\
\hline Tidak Puas & 28 & $56 \%$ \\
\hline Tidak Tahu & 6 & $12 \%$ \\
\hline Jumlah & $\mathbf{5 0}$ & $\mathbf{1 0 0 . 0 0 \%}$ \\
\hline
\end{tabular}

(Sumber: Data primer, 2018)

Oleh karena itu, berdasarkan uraian latar belakang di atas, artikel ini bertujuan untuk mengukur lebih jauh mengenai kinerja pemerintah Daerah Kota Kupang dalam melaksanakan desentralisasi administrasi dalam konteks kualitas pelayanan publik dan nilai survey kepuasan masyarakat (SKM) di Kota Kupang. Pengukuran atas kinerja desentralisasi administrasi di pemerintah 
Kota Kupang didasarkan pada 2 (dua) variabel utama sebagaimana yang terdapat Undang Nomor 23 Tahun 2014 yaitu (1) kualitas pelayanan publik dan (2) Survey Kepuasan Masyarakat Kota Kupang.

\section{METODE}

Metode yang digunakan dalam penelitian adalah deskriptif kualitatif yang bertujuan untuk mendeskripsikan kinerja pemerintah Daerah Kota Kupang dalam melaksanakan desentralisasi administrasi diukur dari perspektif kualitas pelayanan publik dan survey kepuasan masyarakat di Kota Kupang. Metode pengumpulan data menggunakan teknik observasi, survey, wawancara, dan temuan dari kajian literatur, maupun kajian data sekunder.

Lokasi penelitian dilaksanakan pada Pemerintah Kota Kupang, khususnya terkait pengukuran kualitas layanan di lakukan pada Dinas Kependudukan dan Pencatatan Sipil, Dinas Penanaman Modal dan Pelayanan Terpadu Satu Pintu dan Rumah Sakit SK Lerik Kota Kupang sedangkan terkait suvey kepuasan masyarakat, dilakukan pada Dinas Kependudukan dan Pencatatan Sipil, Dinas Penanaman Modal, Pelayanan Terpadu Satu Pintu dan Rumah Sakit SK
Lerik Kota dan 6 (enam) kecamatan di Kota Kupang.

Populasi dalam penelitian ini adalah seluruh masyarakat yang menerima pelayanan kesehatan di Rumah Sakit SK Lerik Kota Kupang, pelayanan di Dinas Kependudukan dan Pencatatan Sipil dan pelayanan kebersihan dari Dinas Lingkungan Hidup dan Kebersihan Kota Kupang. Teknik pengambilan sampel dalam penelitian secara aksidental yaitu teknik yang digunakan ketika besaran populasi tidak diketahui secara jelas, sehingga penentuan sampel dilakukan dengan cara bertemu secara kebetulan (accident) dengan responden yang akan menjadi anggota sampel (Akdon dan Riduwan, 2013).

Adapun jumlah sampel yang kami gunakan yakni berjumlah 50 responden mengingat rata-rata kunjungan responden pada Dinas Kependudukan dan Pencatatan Sipil, Dinas Penanaman Modal dan Pelayanan Terpadu Satu Pintu dan Rumah Sakit SK Lerik Kota Kupang adalah kurang lebih 100 responden. Sedangkan jumlah responden pada survey kepuasan masyarakat pada bidang kebersihan lingkungan kota dan pelayanan air bersih PDAM adalah berjumlah 120 orang. Hal ini dikarenakan survey pada bidang kebersihan dan 
pelayanan air bersih dilakukan pada 6 (enam) kecamatan yang ada di Kota Kupang dengan masing-masing kecamatan sebanyak 20 responden yaitu pada Kecamatan Alak, Kelapa Lima, Maulafa, Oebobo, Kota Raja, dan Kota Lama.

Survey kepuasan masyarakat pada artikel ini menggunakan ketentuan yang dituangkan dalam PermenpanRB Nomor 14 Tahun 2017 terkait 9 (Sembilan) unsur utama yang menjadi fokus penilaian yaitu:

1. Persyaratan: syarat yang harus dipenuhi dalam pengurusan suatu jenis pelayanan, baik persyaratan teknis maupun administratif.

2. Sistem, Mekanisme, dan Prosedur: tata cara pelayanan yang dibakukan bagi pemberi danpenerima pelayanan, termasuk pengaduan.

3. Waktu Penyelesaian: jangka waktu yang diperlukan untuk menyelesaikan seluruh proses pelayanan dari setiap jenis pelayanan.

4. Biaya/Tarif: ongkos yang dikenakan kepada penerima layanan dalam mengurus dan/atau memperoleh pelayanan dari penyelenggara yang besarnya ditetapkan berdasarkan kesepakatan antara penyelenggara dan masyarakat.

5. Produk Spesifikasi Jenis Pelayanan: hasil pelayanan yang diberikan dan diterima sesuai dengan ketentuan yang telah ditetapkan. Produk pelayanan ini merupakan hasil dari setiap spesifikasi jenis pelayanan.

6. Kompetensi Pelaksana: kemampuan yang harus dimiliki oleh pelaksana meliputi pengetahuan, keahlian, keterampilan, dan pengalaman.
7. Perilaku Pelaksana: sikap petugas dalam memberikan pelayanan.

8. Penanganan Pengaduan, Saran dan Masukan: Penanganan pengaduan, saran dan masukan, adalah tata cara pelaksanaan penanganan pengaduan dan tindak lanjut.

9. Sarana dan prasarana: Sarana adalah segala sesuatu yang dapat dipakai sebagai alat dalam mencapai maksud dan tujuan. Prasarana adalah segala sesuatu yang merupakan penunjang utama terselenggaranya suatu proses (usaha, pembangunan, proyek). Sarana digunakan untuk benda yang bergerak (komputer, mesin) dan prasarana untuk benda yang tidak bergerak (gedung).

Terkait dengan teknik pengolahan dan analisis data Survey Kepuasan Masyarakat (SKM) menggunakan "nilai rata-rata tertimbang" masing-masing unsur pelayanan. Setiap unsur pelayanan memiliki penimbang yang sama dengan rumus sebagai berikut:

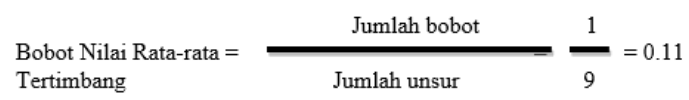

Untuk memperoleh nilai SKM unit pelayanan digunakan pendekatan nilai rata-rata tertimbang dengan rumus sebagai berikut:

$$
\mathrm{SKM}=\frac{\text { Total dari Nilai Persepsi Per Unsur }}{\text { Total Unsur Yang Terisi }} \times \text { Nilai Penimbang }
$$

Untuk memudahkan interpretasi terhadap penilaian SKM yaitu antara 25 100, maka hasil penilaian tersebut di atas 
dikoversikan dengan nilai dasar 25, dengan rumus sebagai berikut:

\section{SKM Unit Pelayanan $\mathrm{x} 25$}

Hasil dari analisa dengan menggunakan rumus di atas kemudian dimasukan dalam tabel dengan kategori seperti dalam tabel 3 di bawah ini:

Tabel 2. Kategori Nilai Survey Kepuasan Masyarakat

\begin{tabular}{|c|c|c|c|c|}
\hline 离 & 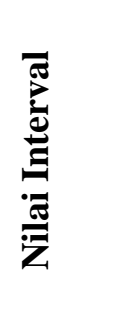 & 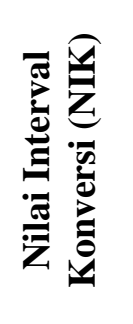 & 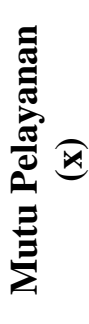 & 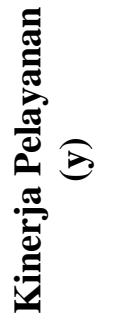 \\
\hline 1 & $\begin{array}{l}1,00- \\
2,5996\end{array}$ & $\begin{array}{l}25- \\
64,99\end{array}$ & $\mathrm{D}$ & $\begin{array}{l}\text { Tidak } \\
\text { Baik }\end{array}$ \\
\hline 2 & $\begin{array}{l}2,60- \\
3,064\end{array}$ & $\begin{array}{l}65,00- \\
76,60\end{array}$ & $\mathrm{C}$ & $\begin{array}{c}\text { Kurang } \\
\text { Baik }\end{array}$ \\
\hline 3 & $\begin{array}{l}3,0644 \\
-3,532 \\
\end{array}$ & $\begin{array}{l}76,61- \\
88,30\end{array}$ & B & Baik \\
\hline 4 & $\begin{array}{l}3,5324 \\
-4,00\end{array}$ & $\begin{array}{l}88,31- \\
100,00\end{array}$ & A & $\begin{array}{c}\text { Sangat } \\
\text { Baik }\end{array}$ \\
\hline
\end{tabular}

Tabel 2 di atas digunakan untuk mengkategorikan jawaban responden terhadap angket/ kuisioner yang telah di analisa, sehingga dapat diambil suatu kesimpulan sampai seberapa baik nilai surbey kepuasan masyarakat (SKM) instansi pemerintah Kota Kupang dalam memberikan pelayanan publik kepada masyarakat.

Selanjutnya teknik untuk menilai kualitas layanan (KL) dihitung dengan menggunakan "nilai rata-rata tertimbang" masing-masing unsur pelayanan.Dalam penghitungan nilai kualitas layanan terhadap 5 dimensi layanan dan masingmasing dimensi terdiri atas 4 unsur kualitas layanan yang dikaji. Setiap unsur pelayanan memiliki penimbang yang sama dengan rumus sebagai berikut:

Bobot Nilai Rata-rata $=$ Tertimbang

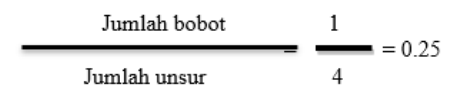

Untuk memperoleh nilai kualitas layanan (KL) Badan/Dinas/Instansi/Kecamatan Pelayanan digunakan pendekatan nilai rata-rata tertimbang dengan rumus sebagai berikut:

$$
\begin{gathered}
\mathrm{KL}=\frac{\text { Total dari Nilai Persepsi Per Unsur }}{\text { Total Unsur Yang Terisi }} \times \text { Nilai Penimbang } \\
\text { Hasil dari analisa dengan }
\end{gathered}
$$
menggunakan rumus di atas kemudian dimasukan ke dalam tabel dengan kategori seperti didalam tabel 4 di bawah ini:

\begin{tabular}{|c|c|c|c|}
\hline $\begin{array}{c}\text { Nilai } \\
\text { Persepsi }\end{array}$ & $\begin{array}{c}\text { Nilai I } \\
\text { Interval }\end{array}$ & $\begin{array}{c}\text { Nilai } \\
\text { Kualitas }\end{array}$ & $\begin{array}{c}\text { Kinerja } \\
\text { Unit }\end{array}$ \\
\hline 1 & $\begin{array}{c}1.00- \\
1.80\end{array}$ & $\mathrm{E}$ & $\begin{array}{l}\text { Sangat } \\
\text { Tidak } \\
\text { Baik }\end{array}$ \\
\hline 2 & $\begin{array}{c}1.81- \\
2.60\end{array}$ & $\mathrm{D}$ & $\begin{array}{l}\text { Tidak } \\
\text { Baik }\end{array}$ \\
\hline 3 & $\begin{array}{c}2.61- \\
3.40\end{array}$ & $\mathrm{C}$ & $\begin{array}{c}\text { Kurang } \\
\text { Baik }\end{array}$ \\
\hline 4 & $\begin{array}{c}3.41- \\
4.20 \\
\end{array}$ & B & Baik \\
\hline 5 & $\begin{array}{l}4.21- \\
5.00\end{array}$ & A & $\begin{array}{c}\text { Sangat } \\
\text { Baik }\end{array}$ \\
\hline
\end{tabular}

Tabel 3. Kategori Nilai Kualitas Layanan 
Selanjutnya, semua data yang telah diperoleh dan dikumpulkan kemudian dianalisis melalui tiga tahap yaitu (1) reduksi data, (2) penyajian data, dan (3) tahap pengambilan keputusan dan verifikasi data.

\section{HASIL DAN PEMBAHASAN}

\section{Nilai Kualitas Pelayanan}

Hasil penelitian atas kuesioner dari 50 responden diperoleh nilai kualitas pelayanan pada 2 (dua) bidang yang menjadi lokus penelitian yaitu bidang kependudukan dan pencatatan sipil pada Dinas Kependudukan dan Pencatatan Sipil dan bidang kesehatan pada Rumah Sakit SK Lerik Kota Kupang. Untuk lebih jelasnya dapat dilihat pada tabel 5 di bawah ini:

Tabel 4. Nilai Indeks Kualitas Layanan

\begin{tabular}{|l|c|c|c|}
\hline \multicolumn{4}{|c|}{ Kategori Indeks Kualitas Layanan } \\
\hline $\begin{array}{c}\text { Nilai } \\
\text { Persepsi }\end{array}$ & $\begin{array}{c}\text { Nilai } \\
\text { Interval }\end{array}$ & $\begin{array}{c}\text { Nilai } \\
\text { Kualitas }\end{array}$ & $\begin{array}{c}\text { Kinerja } \\
\text { Unit }\end{array}$ \\
\hline \begin{tabular}{l} 
1. $\begin{array}{c}\text { Bidang Kependudukan dan Pencatatan } \\
\text { sipil }\end{array}$ \\
\hline 3
\end{tabular} & 2,875 & $\mathrm{C}$ & $\begin{array}{c}\text { Kurang } \\
\text { Baik }\end{array}$ \\
\hline 2. Bidang Kesehatan \\
\hline 3 & 3.35 & $\mathrm{C}$ & $\begin{array}{c}\text { Kurang } \\
\text { Baik }\end{array}$ \\
\hline \multicolumn{4}{|c|}{ 3. Bidang Pelayanan Terpadu Satu Pintu } \\
\hline 4 & 3,85 & B & Baik \\
\hline
\end{tabular}

Dari tabel 5 diatas, diketahui bahwa nilai kualitas layanan di Dinas Kependudukan dan Pencatatan Sipil adalah 2,875, bidang kesehatan adalah 3,35 dan bidang pelayanan terpadu satu pintu adalah 3,85. Hasil ini setidaknya menunjukkan bahwa kualitas layanan pada bidang kependudukan dan kesehatan dikategorikan kurang baik sedangkan bidang pelayanan terpadu satu pintu dikategorikan baik.

Terkait alasan mengapa masyarakat menilai kualitas layanan kurang baik pada bidang kependudukan dan pencatatan sipil diantaranya adalah karena pertama, prosedur yang terkesan menyusahkan artinya sejumlah responden mengatakan bahwa prosedur dan syarat pengurusan produk administrasi pada Disdukcapil Kota Kupang masih tumpang tindih dan bahkan tidak jelas informasinya mulai dari tingkat kelurahan, kecamatan sampai pada tingkat dinas. Sebagian besar responden mengeluhkan bahwa untuk mengurus sejumlah surat-surat seperti KTP/ KK atau Akta, mereka perlu bolak-balik Kantor Disdukcapil minimal 3 (tiga) kali. Namun mereka juga mengakui bahwa hal ini tidak terjadi jika mereka mengenal petugas dengan baik dalam hubungan sebagai teman, saudara atau sanak famili. Alasan kedua yaitu sejumlah responden masih mengeluhkan waktu pengurusan KTP atau KK maupun akta pencatatan sipil masih dinilai cukup lama dari batas waktu yang ditentukan. Bahkan ada 
sampai sebulan lebih KTPnya tidak jadi karena berbagai kendala teknis. Alasan ketigas, Kurangnya kedisiplinan petugas pelayanan. Para responden mengeluhkan tentang disiplin para petugas pemberi layanan. Umumnya mereka mengatakan ada 3 loket, tapi yang beroperasi biasanya 1 atau 2 loket saja, apalagi jika sudah mendekati jam makan siang atau pulang kerja. Hal ini menyebabkan antrian menjadi panjang dan memakan waktu yang lama. Disamping itu juga, responden menilai sikap petugas layanan yang terkadang tidak ramah dimana sering menggunakan nada yang tinggi dan bersikap acuh kepada mereka. Hal ini tentunya menyebabkan kurangnya kenyamanan yang dirasakan oleh masyrakat pada saat proses pelayanan. Dan alasan yang keempat adalah masyarakat sering kali merasakan ketidakadilan didalam proses pelayanan seperti beberapa orang yang tidak melalui antrian untuk mengurus berbagai suratsurat di Dinas melainkan langsung masuk ke ruang pelayanan. Selain itu, ada juga yang mendapatkan pelayanan yang cepat dan KTP/ KKnya telah selesai diproses kurang dari 2 hari sedangkan responden yang lain perlu menunggu sampai 2 minggu dan bahkan ada yang sampai berbulan-bulan akibat berkas usulannya hilang.

Setidaknya fenomena yang terjadi bukanlah sesuatu yang baru, karena berdasarkan hasil penelitian dari Aksa (2018) diketahui bahwa diskriminasi pelayanan juga terjadi pada Dinas Kependudukan dan Pencatatan Sipil Kabupaten Lampung Utara yang mana terjadi dalam bentuk membeda-bedakan waktu dan biaya pelayanan, sikap petugas serta prosedur yang ditetapkan terhadap masyarakat biasa yang mengikuti prosedur pelayanan dengan masyarakat dari golongan tertentu seperti orang kaya, pejabat, tokoh masyarakat dan saudara atau kenalan pegawai di Dinas Kependudukan dan Pencatatan Sipil Kabupaten Lampung Utara. Lebih lanut fenomena ini terjadi dikarenakan dikarenakan budaya pelayanan yang masih terpengaruh kebudayaan lokal dan budaya hierarkis birokrasi menciptakan budaya paternalistis dalam pelayanan yang berpihak kepada pejabat dan penguasa, dan motif sosial seperti kedudukan seseorang.

Hal yang sama juga disampaikan pada jawaban responden terkait alasanalasan dibalik penilaian kualitas layanan kesehatan yaitu: pertama, sebagian besar responden menilai pihak rumah sakit 
masih belum memberikan pelayanan yang optimal khususnya bagi masyarakat pengguna BPJS, dimana seringkali ditempatkan di kelas umum, hal ini berbeda jika yang sakit adalah masyarakat golongan menengah keatas, mereka pastinya mendapatkan pelayanan yang terbaik. Oleh karenanya, maka tidak heran masyarakat mempersepsikan kualiatas layanan di Rumah Sakit Kota Kupang tidak baik, sehingga pihak Rumah Sakit Kota Kupang perlu melakukan sejumlah pembenahan atas sistem prosedur layanan meliputi biaya pelayanan, sikap petugas layanan, waktu layanan, dan keadilan dalam mendapatkan pelayanan.

Realitas di atas menunjukkan kebijakan desentralisasi tidak selalu memberikan dampak positif terhadap peningkatan kualitas layanan. Setidaknya, hal ini juga terjadi sebagaimana hasil penelitian yang dilakukan oleh Conyers (2007) di negara-negara sub-Sahara, dan Robinson (2007: 2) di negara-negara di Asia Selatan dan Afrika Barat, dimana mereka menemukan bahwa desentralisasi tidak meningkatkan kualitas layanan dan justru kualitas layanan menjadi menurun atau tetap tidak berubah. Demikian pula dengan penelitian yang dilakukan oleh Ahmad dan Shah (2005) yang menemukan bahwa manfaat desentralisasi pada pemberian layanan tidak bisa terwujud karena terbatasnya wewenang pejabat lokal untuk menyesuaikan diri dengan preferensi masyarakat lokal. Selain itu pula, hasil yang tidak jauh berbeda ditunjukkan oleh hasil penelitian Tidemand dan Msami (2010) di Tanzania yang menemukan fakta bahwa lebih dari tiga perempat warga tidak senang dengan kualitas layanan di berbagai sektor seperti jalan lokal, pasar, klinik kesehatan, air layanan, pasokan listrik dan layanan penyuluhan pertanian.

\section{Survei Kepuasa Masyarakat (SKM)}

Hasil penelitian atas kuesioner dari 50 responden pada bidang kependudukan dan pencatatan sipil, bidang pelayanan terpadu satu pintu dan bidang kesehatan, dan 120 responden pada bidang kebersihan dan bidang pelayanan air bersih, maka diperoleh nilai kepuasan masyarakat sebagaimana akan diuraikan lebih jelasnya di bawah ini: 
Tabel 5. Nilai Survey Kepuasan Masyarakat (SKM)

\begin{tabular}{|c|c|c|c|}
\hline \multicolumn{4}{|c|}{ Kategori Nilai Kepuasan Masyakat } \\
\hline $\begin{array}{c}\text { Nilai } \\
\text { Persepsi }\end{array}$ & $\begin{array}{c}\text { Nilai } \\
\text { Interval }\end{array}$ & $\begin{array}{c}\text { Mutu } \\
\text { Pelayanan } \\
(x)\end{array}$ & $\begin{array}{c}\text { Kinerja } \\
\text { Pelayanan } \\
(\mathbf{y})\end{array}$ \\
\hline
\end{tabular}

1. Bidang Kependudukan dan Pencatatan sipil

\begin{tabular}{|l|c|c|c|}
\hline 2 & 2,63 & $\mathrm{C}$ & $\begin{array}{c}\text { Kurang } \\
\text { Baik }\end{array}$ \\
\hline 2. Bidang Kesehatan \\
\hline 3 & 3,15 & B & Baik \\
\hline
\end{tabular}

3. Bidang Layanan Terpadu Satu Pintu

\begin{tabular}{|l|c|c|c|}
\hline 3 & 3,45 & B & Baik \\
\hline 4. & Bidang Kebersihan Lingkungan Kota \\
\hline 2 & 2,95 & $\mathrm{C}$ & $\begin{array}{c}\text { Kurang } \\
\text { Baik }\end{array}$ \\
\hline
\end{tabular}

5. Bidang Pelayanan Air Bersih PDAM Kota Kupang

\begin{tabular}{|c|c|c|c|}
\hline 2 & 2,35 & C & $\begin{array}{c}\text { Kurang } \\
\text { Baik }\end{array}$ \\
\hline
\end{tabular}

(Sumber: Data Primer, 2018)

Pertama, pada bidang kependudukan dan pencatatan sipil sebagaimana pada tabel 6 di atas, diperoleh nilai indeks kepuasan masyarakat atas layanan kependudukan dan pencatatan sipil sebesar 2,63 yang berkategori $\mathrm{C}$ atau kurang baik. Sesungguhnya kategori $\mathrm{C}$ ini bermakna bahwa masyarakat merasa tidak puas atas layanan pemerintah di bidang kependudukan dan pencatatan sipil, dimana hal ini sesungguhnya merupakan dampak dari buruknya kualitas layanan yang diberikan pemerintah. Oleh karenanya penulis menyarankan agar pemerintah segera untuk dapat melakukan reformasi pelayanan publik guna meningkatkan kualitas pelayanann publik, sehingga tingkat kepuasan masyarakat pun semakin bertambah. Mengingat sesungguhnya indeks kepuasan masyarakat merupakan indikator kunci didalam menilai kinerja pemerintah dalam melaksanakan berbagai aktivitas dan aturannya, khususnya terkait urusan desentralisasi administratisi sesuai dengan Undang-undang nomor 23 Tahun 2014.

Kedua, pada bidang kesehatan sebagaimana pada tabel 6 di atas, diketahui indeks kepuasan masyarakat atas layanan kesehatan di Rumah Sakit SK Lerik Kota Kupang adalah 3,15 atau berkategori B (baik). Hal ini dikarenakan meskipun kualitas layanan rumah sakit dipersepsikan masih kurang baik oleh para responden namun fasilitas Rumah Sakit Kota Kupang dinilai cukup memadai dan nyaman bagi para pengguna jasa rumah sakit sehingga hal inilah yang kemudian menyebabkan angka kepuasan masyarakat menjadi naik ke kategori baik.

Ketiga, bidang layanan terpadu satu pintu dikategorikan baik dengan nilai kepuasan masyarakat 3,45. Penilaian ini dikarenakan menurut responden mengaku puas dengan pelayanan yang diberikan dilihat dari sisi kejelasan prosedur dan 
biaya, ketepatan waktu, dan sikap dari petugas pelayan yang cukup ramah meskipun pada beberapa kesempatan diakui oleh beberapa responden tidak memberikan pelayanan sebagaimana yang mereka harapkan. Namun dari keseluruhan proses pelayanan diakui sudah sangat memuaskan.

Keempat, pada bidang Kebersihan Lingkungan Kota diketahui nilai kepuasan masyarakat atas layanan kebersihan, khususnya layanan pengangkutan sampah di Kota kupang adalah 2, 95 atau berkategori C (kurang baik). Hal ini dikarenakan sebagian besar responden masih merasa belum puas dengan pelayanan Dinas Lingkungan Hidup dan Kebersihan Kota Kupang yang disebabkan oleh sejumlah alasan seperti "para petugas kebersihan sangat jarang dan belum dilakukan secara terjadwal datang untuk mengangkut tumpukan sampah yang ada di lingkungan tempat tinggal kami."

Kelima, pada bidang pelayanan air bersih (PDAM) diperoleh nilai indeks kepuasan masyarakat atas layanan air bersih hanya mencapai angkaa 2,35 atau berkategori C (kurang baik). Hal ini dikarenakan sebagaian besar masyarakat yang menjadi responden dalam penelitian mengatakan bahwa PDAM didalam memberikan pelayanan air bersih dinilai tidak optimal, karena pada umumnya layanan air bersih itu diberikan hanya 1 (satu) minggu sekali kepada masyarakat, khususnya pada musim kemarau. Selain itu masyarakat juga mengeluhkan respon yang lambat dari pihak PDAM didalam menanggapi keluhan dari masyarakat selaku pelanggan mereka seperti perbaikan pipa air, atau pengukur meteran yang bermasalah. Sehingga tidak jarang masyarakat lebih memilih membeli "air tanki" untuk memenuhi kebutuhan air bersih sehari-harinya.

Jika melihat fakta empirik di atas, kita dapat kembali menyimpulkan bahwa desentralisasi tidak selalui dapat memenuhi tujuan utamanya desentralisasi yaitu meningkatkan kualitas layanan dan kepuasan masyakarakat (Burns et al. 1994: 4; Crook \& Manor 1998). Hal ini sesungguhnya tidak mengherankan, karena dari berbagai literatur empiris di negara-negara berkembang telah mengungkapkan serangkaian hasil yang mengecewakan terkait dengan dampak desentralisasi baik pada kualitas pemerintahan dan pengiriman layanan. Misalnya, Azfar (1999) dan Gabral (2011) menemukan bahwa desentralisasi tidak meningkatkan kualitas pemerintahan dan bahwa di lebih dari 
setengah negara di Afrika, gagal meningkatkan otoritas pengambilan keputusan dewan lokal dalam alokasi sumber daya keuangan, mengingat fakta bahwa pengeluaran pemerintah daerah berjumlah kurang dari $5 \%$ dari pengeluaran publik nasional. Hal yang sama juga ditemukan dari hasil penelitian yang dilakukan oleh Fanggidae, Fajri, Hidayatul, Yuanjaya (2016) bahwa meskipun Provinsi Papua Barat, Indonesia telah mendapat dana otonomi khusus dari Pemerintah Pusat namun dalam tataran empiric masih belum dapat mencapai tingkat kesejahteraan yang diharapkan. Hal ini disebabkan karena sumberdaya yang dimiliki terhenti pada birokrasi dan pemerintah sehingga tidak dapat mensejahterakan masyarakat.

\section{SIMPULAN}

Penilaian kinerja merupakan suatu proses menilai kinerja organisasi dengan tujuan untuk memberikan masukan bagi perbaikan organisasi di masa depan. Pengukuran desentralisasi administrasi yang didasarkan pada variabel kualitas pelayanan dan survey kepuasan masyarakat menunjukan bahwa kualitas layanan yang diberikan oleh Pemerintah Kota Kupang belum maksimal. Hal ini terlihat pada kualitas layanan pada bidang kependudukan $(2,875)$ dan kualitas layanan kesehatan $(3,35) \quad$ yang dikategorikan $\mathrm{C}$ atau kurang baik. Namun hanya layanan terpadu satu pintu saja $(3,85)$ yang sudah dinilai baik. Disisi lain, hasil dari survey kepuasan masyarakat menunjukan bahwa hanya bidang kesehatan dan bidang layanan terpadu satu pintu saja yang dikategorikan B atau baik dengan nilai masing-masing 3,15 dan 3,44 sedangkan bidang kependudukan dengan nilai 2,63, layanan kebersihan dengan nilai 2,95 dan layanan air bersih dengan nilai 2,35 masih dikategorikan $\mathrm{C}$ atau kurang baik.

Untuk itu guna memperbaiki kualitas pelayanan, maka Pemerintah Kota Kupang perlu melakukan reformasi pelayanan pada tiga aspek utama yaitu: Pertama, aspek penataan kelembagaan dan SDM; Kedua, aspek penyelenggaraan pelayanan; dan Ketiga, aspek inovasi organisasi dengan pengembangan penggunaan teknologi informasi melalui pengembangan inovasi-inovasi pelayanan yang mana hal ini dapat berdampak pada efisiensi, dan efektivitas pelayanan yang lebih baik.

\section{DAFTAR PUSTAKA}

Ahmad, J., S. Devarajan, S. Khemani, \& S. Shah. (2005). Decentralization and Service Delivery (Working 
Paper 3603). Washington DC: World Bank.

Akdon dan Riduwan. (2013). Rumus dan Data dalam Aplikasi Statistika. Bandung: Alfabeta.

Albrecht, K. \& R. Zemke. 1990. Service America: Doing Business in the Service Economy, Homewood: Dow Jones-Irwin.

Aksa, Rahadian. (2018). Discrimination of Public Service in Population and Civil Registration Agency of North Lampung Regency. Jurnal Natapraja, Volume 6 Nomor 1 Tahun 2018, pp.21-24, https://journal.uny.ac.id/index.php/ natapraja

Azfar, O., S. Kahkonen, A. Lanyi, P. Meagher \& R. Diana. (1999). Decentralization, Governance and Public services: The impact of Institutional Arrangements. A review of the literature. IRIS Center: University of Maryland.

Azfar, O., S. Kahkonen \& P. Meagher. (2001). Conditions for Effective Decentralized Governance: A Synthesis of Research Findings. IRIS Center: University of Maryland.

Bryant, Coralie dan Louis G. White. 1987. Manajemen Pembangunan untuk Negara Berkembang. Jakarta: LP3ES.

Burns, D., R. Hambleton \& P. Hoggett. (1994). The politics of decentralization. London: The MacMillan Press.

Conyers, D. (2007). Decentralization and Service delivery: Lessons from sub
Saharan Africa. IDS bulletin, 38:18-32.

Crook, R.C. \& J. Manor. (1998). Democracy and Decentralization in South Asia and West Africa: Participation, Accountability and Performance. Cambridge: Cambridge University Press.

Fanggidae, Ivan Giddeon; Fajri, Hidayatul; Yuanjaya, Pandhu. (2016). Menelisik Kinerja Governance di Daerah Otonomi Khusus Papua Barat. Jurnal Natapraja, Volume 4 Nomor 1 Tahun 2016, https://journal.uny.ac.id/index.php/ natapraja.

Fitriana, Kurnia Nur. (2015). Manajemen Perubahan: Studi Pada Reformasi Pelayanan Perizinan di Kota Yogyakarta. Jurnal Natapraja, Volume 3 Nomor 1 Tahun 2015, https://journal.uny.ac.id/index.php/ natapraja.

Gabral, L. (2011). Decentralisation in Africa: Scope, Motivations and Impact on Service Delivery and Poverty. Overseas Development Institute, Working paper 020.

Goetsch, David. L, Staanley B.Davis. (2002). Quality Management, Introduction to Total Quality Management for Production, processing, and services. New Jersey: Prentice Hall.

Hossain, A. (2010). Administrative decentralization: A Framework for Discussion and its Practices in Bangladesh. Bangladesh: University of Rajshah. 
Kaufmann, M., A. Kraay \& Z.P. Lobaton. (1999). Governance matters. Six new aggregate measures capturing various dimension of governance provide new evidence of strong causal relationship between governance to better development outcome. Washington DC: World Bank Policy Research Working Paper 2196.

Kotler, Philip. 2005. Manajemen Pemasaran. Jilid 1 dan 2. Jakarta: PT Indeks Kelompok Gramedia.

Litvack, J., J. Ahmad\& R. Bird. (1998). Rethinking decentralization in developing countries. Washington DC: World Bank sector studies series.

Litvack, Jenie. (1999). Decentralization. Washington DC: World Bank.

Osborne, David, and Ted Gaebler. (1992). Reinventing Government: How The Entrepreneur Spirit is Transforming The Public Service. Jakarta: Pustaka Binaman Pressindo.

Rayi Endah. (2008). Analisis Kualitas Layanan, Kualitas Produk, dan Harga Terhadap Kepuasan Pelanggan. Skripsi, Universitas Diponegoro, Semarang.

Robinson, M. (2007). Introduction: Decentralizing Service Delivery? Evidence and Policy Implications. IDS Bulletin, 38:1-6.

Rondinelli, D.A. (1981). Government Decentralization in Comparative Perspective: Theory and Practice in Developing Countries.
International Review of Administrative Science, 47:133-45.

Schneider, A. (2003). Decentralization: Conceptualization and measurement. Studies in international comparative development, 38:32-56.

Sinambela, Lijan Poltak. (2008). Reformasi Pelayanan public: teori, kebijakan dan implementasi. Jakarta: Bumi Aksara.

Smith, Brian C. (1985). Decentralization: The Territorial Dimension of The State. London: George Allen \& Unwin.

Sugiyono. (2017). Metode Penelitian Kuantitatif, Kualitatif, dan $R \& D$. Bandung: Alfabeta, CV.

Supraptono, Suryo. (1998). Analisis Kualitas Pelayanan dan Kepuasan Pasien Rawat Inap RSUD Dr. MURJANI. Tesis, Universitas Gajah Mada, Yogyakarta.

Tidemand, P. \& J. Msami. (2010). The impact of local government Reforms in Tanzania. Special paper 10/1. Dar es Salaam: REPOA.

Widodo, Joko. (2001). Good Governance; Telaah dari Dimensi Akuntabilitas Dan Kontrol Birokrasi Pada Era Desentralisasi dan Otonomi Daerah. Insan Cendikia, Surabaya.

Zeithaml, Valarie A., A. Parasuraman \& Leonard L. Berry. (1990). Delivering Quality Service. New York: The Free Press. 